\title{
Use of proscribed chloroquine is associated with an increased risk of pfcrt T76 mutation in some parts of Ghana
}

\author{
Kwame K Asare ${ }^{1}$, Johnson N Boampong ${ }^{1 *}$, Richmond Afoakwah ${ }^{1}$, Elvis O Ameyaw ${ }^{1}$, Rakesh Sehgal ${ }^{2}$
} and Neils B Quashie ${ }^{3}$

\begin{abstract}
Background: After years of disuse of chloroquine (CQ) as first-line anti-malarial drug in Ghana, reports from molecular studies conducted in parts of the country indicate varying prevalence of T76 mutation in the pfcrt gene. This situation has several health implications, one being that mutations that confer resistance to CQ have been reported to show substantial cross-resistance to other anti-malarial drugs. It is important to identify some of the factors contributing to the continuous presence of CQ resistance markers in the country. This study determined the prevalence of T76 mutation in pfcrt gene of Plasmodium falciparum isolates collected from selected areas of the Central region of Ghana and correlated with the level of CQ use in these areas.
\end{abstract}

Methods: Plasmodium falciparum DNA was extracted from collected blood-blot filter paper samples in the study sites. The prevalence of T76 point mutation in pfcrt gene was assessed using nested PCR followed by RFLP. $\mathrm{CQ}$ from pharmacy and chemical shops was obtained using mystery buying method. The extent of CQ use by the participants was determined by measuring the level of the drug in their urine samples using the Saker-Solomon method.

Results: Of the 214 P. falciparum isolates analysed, $71.9 \%$ were found to have T76 mutation of pfcrt gene. The study revealed that $14.49 \%$ of community pharmacies and chemical shops had stocks of CQ for sale while $16.9 \%$ of the participants had CQ in their urine samples. There is five times more risks of becoming infected with CQ resistant strain for staying in an area where $C Q$ is stocked for sale $[R R=0.20, p<0.0001]$ and thirteen times more risks of having CQ-resistant mutant from those who still use CQ than non-users [OR $=0.08, \mathrm{p}<0.0001]$.

Conclusion: This study has shown that high variation in the prevalence of T76 mutations of $P$. falciparum is linked with the level of CQ stocking and usage within study area.

Keywords: Plasmodium falciparum, Chloroquine resistant markers, Chloroquine usage, Mutation, pfcrt, Ghana

\section{Background}

Undeniably, anti-malarial drug resistance remains a major obstacle to malaria control in the disease endemic areas. Based on reports of high chloroquine (CQ) treatment failure in Ghana and the recommendations of the World Health Organization (WHO) [1-3], CQ was replaced with artemisinin-based combination therapy (ACT) in 2004. Interestingly, high prevalence of $\mathrm{CQ}$ resistant mutants

\footnotetext{
* Correspondence: jonboamus@yahoo.com

${ }^{1}$ Department of Biomedical and Forensic Sciences, University of Cape Coast, Cape Coast, Ghana

Full list of author information is available at the end of the article
}

have been reported in different parts of the country by several researchers after the change in the malaria treatment policy $[4,5]$ though others have reported decreased trend in prevalence and resistance in vitro [6,7].

Substitution of adenylate with cytidylate at position 76 of Pfcrt gene which changes lysine to threonine (K76 to T76) is a single molecular marker that strongly correlates with CQ drug resistance in Plasmodium falciparum in most malaria endemic areas $[8,9]$. Similarly, other mutations at different codons of $p f c r t$ gene have also shown association with CQ resistance $[8,10,11]$. 
In a retrospective study conducted from 2003 to 2010 by Duah and colleagues, they showed that there is decrease in T76, although the prevalence varies from study site to study site [6]. Earlier, Abruquah and colleagues had reported $88.6 \% \mathrm{~K} 76 \mathrm{~T}$ prevalence in Kumasi [4], while Kwansa-Bentum and colleagues reported 51.6\% K76T prevalence in southern part of Ghana [5]. A study conducted in 2004 by Duah and colleagues reported different T76 mutations among the various sentinel sites for their studies [12]. In that study, they reported T76 prevalence to be $80 \%$ at Hohoe, $46 \%$ at Navrongo, $98 \%$ at Tarkwa, $61 \%$ at Sunyani \& 46\% in Yendi [12]. This study was conducted to find out the prevalence of T76 mutation in the selected health facilities and to determine the cause for the high prevalence of CQ resistance.

\section{Methods}

\section{Study sites}

Samples for this study were collected from municipal hospital (Cape Coast), district hospitals (Twifo Praso and Assin Foso) and health centres (Elmina) all in the Central region of Ghana. Cape Coast metropolis covers an area of 122 square kilometres (sq. km) and is the smallest metropolis in the country. The capital, Cape Coast, is also the capital of the Central Region. Cape Coast metropolitan hospital serves an average population of 140,000 and receives a yearly attendance of 80,000 to 100,000 patients. It is located in Bakaano a suburb of Cape Coast. Elmina is the district capital of Komenda-Edina-Eguafo-Abirem (KEEA) and covers an area of 1,372.45 square kilometres. The Elmina Urban Health Centre caters for inhabitants of an area of 600 sq. $\mathrm{km}$ comprising 22 villages with catchment population of about 50,000. Twifo Praso is the district capital of the Twifo-Heman-Lower Denkyira district. The district covers an area of 1,199 square $\mathrm{km}$ with about 1,510 settlements. Twifo Praso Government hospital is a district hospital. It a serves catchment population of 15,351 , distributed in Twifo Praso and neighbouring towns. The Assin North district covers an area of about 1,500 sq. km. and comprises about 1,000 settlements. The St. Francis Xavier Hospital still remains the District Hospital for both Assin north and Assin south districts covering a land mass of 1,255 sq. km (1/4) of Central Region. The hospital has catchment population of 207,000.

\section{Ethical considerations}

The study was approved by the Ghana Health Service Ethics Committee (GHS-ERC-17/01/12) and University of Cape Coast Institutional review Board (UCCIRB/28/ 09/3.1.1). Approval was also sought from the Medical directors and administrators of the various health facilities before sample collection. Anonymity of study subjects was strictly enforced. Samples were collected and handled solely by trained laboratory technologists. The study posed no risk to participants except for the transient pain they felt during blood collection. Sterile techniques were employed using disposable new materials at all times.

\section{Recruitment of participants}

The study was explained to the prospective participants who were referred to the laboratory for malaria test. Informed consent was sought from those who satisfied the inclusion criteria and agreed to be part of the study. A patient was included into the study if he/she was older than six months old, had Plasmodium parasitaemia, was conscious, non-haemophilic, and did not experience palpitation at the time of sample collection.

\section{Sample collection}

One millilitre $(1 \mathrm{ml})$ of blood sample was collected from each participant into tubes containing EDTA by trained and licensed medical laboratory technologists from the health facilities. Also $10 \mathrm{ml}$ mid stream urine samples were collected at the time of participant visit for CQ analysis. All samples collected were stored on ice and transported to the Parasitology Research Laboratory of the Department of Biomedical and Forensic Sciences, University of Cape Coast where they were stored at $-20^{\circ} \mathrm{C}$. About six drops of blood sample collected was spotted on a 3MM Whatman filter paper. The blood spots were airdried and stored at $-20^{\circ} \mathrm{C}$ in zip-locked plastic envelopes containing silica gel.

\section{Detection of pfcrt polymorphisms}

DNA was extracted from the perforated portions of blood spotted filter-paper using chelex extraction method [13]. PCR followed by restriction fragment length polymorphism (RFLP) was used to detect the mutations following published protocols [14]. The primers for the DNA amplification of pfcrt are shown in Table 1.

\section{Mystery buying of CQ}

Mystery buyers were used to investigate if Chemical shops and Community Pharmacies in these communities still stocked CQ using convenient sampling method. Surrogate buyers visited chemical and pharmacy shops located in the study areas to buy CQ.

\section{Urine $\mathrm{CQ}$ assay}

The specific gravity of urine samples were determined using urinometer (BD Adams ${ }^{\mathrm{TH}}$, Canada). The presence of CQ in the participants' urine was detected with SakerSolomon's method [15]. A standard curve was estimated from standard concentrations $(0,2,3,4$, or $5 \mu \mathrm{g} / \mathrm{ml})$ of CQ (Sigma-Aldrich, UK). The presence of CQ in the urine samples that tested positive to Saker-Solomon method was determined spectrophotometrically. In the Saker-Solomon 
Table 1 Oligonucleotide sequence and PCR conditions used to detect PfcrtK76T SNP

\begin{tabular}{llll}
\hline Primer & Sequence $\left(\mathbf{5}^{\prime}-\mathbf{3}^{\prime}\right)$ & Size $\mathbf{( b p )}$ & PCR condition \\
\hline $\begin{array}{l}\text { Primary amplification } \\
\text { CRT1F }\end{array}$ TTGTCGACCTTAACAGATGGCTCAC & 526 & $96^{\circ} \mathrm{C}, 15^{\prime}$ followed by $45 X\left(96^{\circ} \mathrm{C}, 30^{\prime \prime} ; 56^{\circ} \mathrm{C}, 90^{\prime \prime} ; 72^{\circ} \mathrm{C}, 90^{\prime \prime}\right) ; 72^{\circ} \mathrm{C}, 10^{\prime}$ \\
$\begin{array}{l}\text { CRT1R } \\
\text { Nested amplification }\end{array}$ & & \\
$\begin{array}{l}\text { CRT2F } \\
\text { CRT2R }\end{array}$ & CTTGTCTTGGTAAATGTGCTC & 200 & $96^{\circ} \mathrm{C}, 15^{\prime}$ followed by $45 X\left(96^{\circ} \mathrm{C}, 30^{\prime \prime} ; 50^{\circ} \mathrm{C}, 90^{\prime \prime} ; 72^{\circ} \mathrm{C}, 90^{\prime \prime}\right) ; 72^{\circ} \mathrm{C}, 10^{\prime}$ \\
\hline
\end{tabular}

method the urine samples were diluted and $10 \mu \mathrm{l}$ of each sample was added to a well in triplicates. The absorbance of the urine samples was read at $565 \mathrm{~nm}$. The concentrations were determined from the standard curve. A standard CQ concentration which corresponds to each of the urine samples was also prepared read at $565 \mathrm{~nm}$. The cross-reactivity for each sample was then determined using the formula; Absorbance of Urine sample/Absorbance CQ standard. The urine samples that tested positive qualitatively to Saker-Solomon's urine CQ method but the samples whose error margins fell below or above $5 \%$ error margin were considered to be cross-reacting with other compounds (such quinine) after estimating the ratios of absorbance of samples to absorbance of standards of equal concentrations.

\section{Data analysis}

Data were entered and validated using Microsoft Office Excell $^{\odot} 2007$ (Microsoft Corporation) and analysed with SPSS $^{\oplus}$ Statistical Software version 16 (SPSS Inc.) and MedCalc $^{\oplus}$ statistical software version 12.7.2 (MedCalc software, Ostend, Belgium). The count of samples with mutant and wild-type alleles was used to generate the prevalence of the alleles. Pearson chi-square test and relative risk were used to compare the risks of becoming infected with CQ-resistant P. falciparum when one stays in an area where pharmacies and chemical shops stock CQ. Pearson chi-square test and Odd ratio were also used to compare the risks of the use CQ and becoming infected with CQ-resistant P. falciparum strains. The Pearson chi-square test was used to determine the association between the alleles and CQ stock and CQ usage.

\section{Results}

A total of 444 participants had their urine successfully examined for the presence of CQ in this study; 56 from Cape Coast, 105 from Elmina, 143 from Assin Foso and 140 from Twifo Praso. The corresponding prevalence of patients with detectable CQ in their urine per the study sites were $23.21 \%, 11.43 \%, 18.88 \%$ and $16.43 \%$ respectively. In all, 75 of participants had CQ in their urine representing $16.89 \%$ prevalence of CQ consumption in the four study areas. The total prevalence of CQ stocks within the four study areas were 14.49\% (10/69); $21.05 \%$ $(4 / 19)$ in Cape Coast, 9.09\% (1/13) in Elmina, 16.67\% $(3 / 19)$ in Assin Foso and 10.53 (2/19) in Twifo Praso (Table 2).

Two hundred and fourteen (214) of the P. falciparum isolates had DNA extracted and analyzed for pfcrt T76 mutant allele. Fifty six (56) of the isolates were from Cape Coast, 52 from Elmina, 54 from Assin Foso and 52 from Twifo Praso. The overall prevalence of pfcrt T76 mutation was $71.96 \%$ (154/214); $80.4 \%$ in Cape Coast, $78.8 \%$ in Elmina, $75.9 \%$ in Assin Foso and $50.0 \%$ in Twifo Praso. The distribution of the two alleles; wild type (K76) and mutant type (T76) from the four study sites is shown in Table. Significant association was found between prevalence of CQ stocks and prevalence of $p f c r t$ T76 mutant allele in all the study sites, except Twifo Praso as shown in Figure 1. Additionally, the levels of CQ usage within a study site were significantly associated with the prevalence of pfcrt T76 mutant allele. In Cape Coast and Assin Foso, a high number of participants (23.21 and $18.88 \%$ respectively) had CQ in their urine samples, and higher prevalence of pfcrt T76

Table 2 Prevalence of subjects that still use CQ and the drug shops that had CQ stocks at the study sites

\begin{tabular}{|c|c|c|c|}
\hline Study sites & $\begin{array}{l}\text { Percentage prevalence } \\
\text { of pfcrt mutations }\end{array}$ & $\begin{array}{l}\text { Percentage of subjects with } \\
\text { CQ in urine }(n / N)\end{array}$ & $\begin{array}{l}\text { Percentage of drug shops } \\
\text { with CQ stocks (n/N) }\end{array}$ \\
\hline Cape Coast & 80.4 & $23.21(13 / 56)$ & $21.05(4 / 19)$ \\
\hline Elmina & 78.8 & $11.43(12 / 105)$ & $9.09(1 / 13)$ \\
\hline Assin Foso & 75.9 & $18.88(27 / 143)$ & $16.67(3 / 19)$ \\
\hline Twifo Praso & 50.0 & $16.43(23 / 140)$ & $10.53(2 / 19)$ \\
\hline Total number & 71.9 & $16.89(75 / 444)$ & $14.49(10 / 69)$ \\
\hline
\end{tabular}

$\mathrm{n}$ represent the number of subjects that had $\mathrm{CQ}$ in their urine.

$\mathrm{N}$ represent the total number of subject whose urine were tested for CQ. 


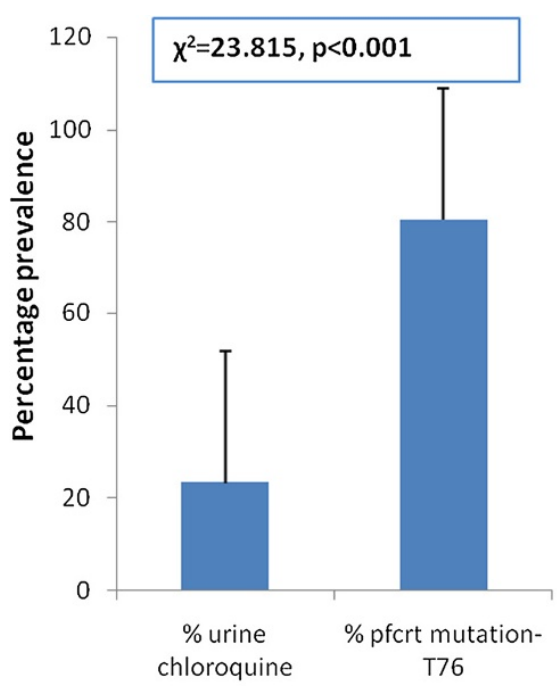

Cape Coast

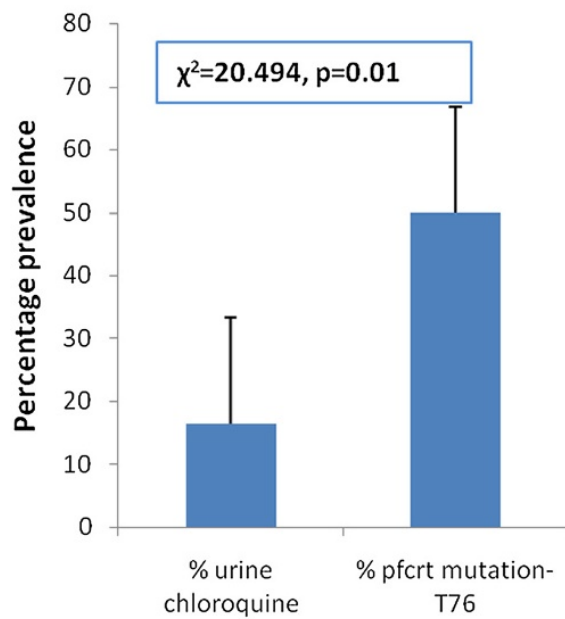

Twifo Praso

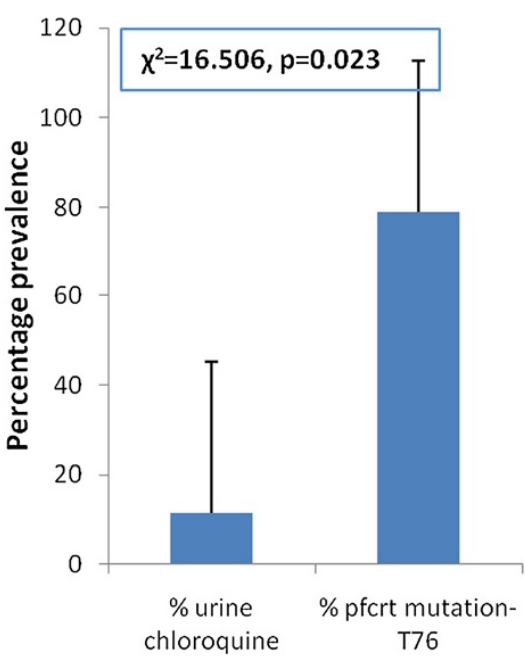

Elmina

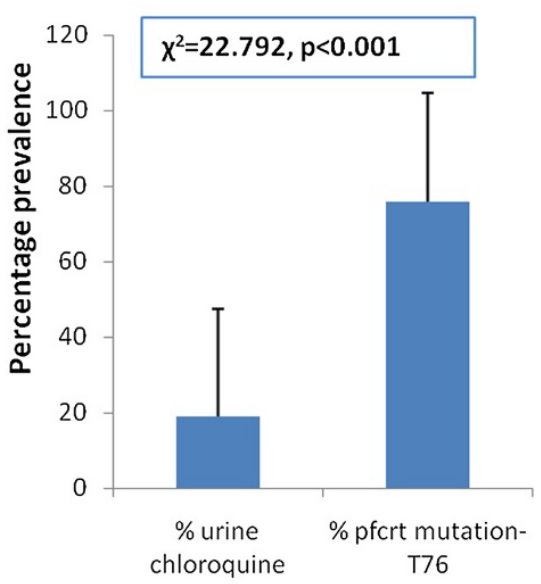

Assin Foso

Figure 1 Association between chloroquine stocking in a community and prevalence of K76T of pfcrt K76T mutation. The \% of community pharmacies and chemical shops that are still stocking and selling chloroquine in the study communities.

mutant P. falciparum in their samples $(\mathrm{p}<0.0001)$ as compared to Elmina $(p=0.023)$ and Twifo Praso $(p=0.01)$ as shown in Figure 2.

The study also demonstrated that individuals who stay in an area where community pharmacies and chemical shops had CQ stocks have five times more risk of become infected with T76 resistant $P$. falciparum strain than individuals who stay in CQ free area $[R R=0.20$, 95\% CI (0.11-0.34), $\mathrm{p}<0.001]$. As shown in Figure 1, there was significant association between CQ stock within the communities and T76 mutation except Twifo Praso. Cape Coast had the highest number of community pharmacies and chemical shops that stocked CQ and the risk of individuals becoming infected with T76 resistant mutant is $26 \%$ [ $R R=0.26,95 \%$ CI $(0.11-0.63)$, $\mathrm{p}<0.001$ ] while individuals staying in Elmina, study site with the least number of community pharmacies and chemical shops stocking CQ had 10\% risks of becoming infected with T76 resistant mutant $[R R=0.10,95 \% \mathrm{CI}$ (0.02-0.66), $\mathrm{p}<0.05]$. Again, individuals who still use CQ for malaria treatment had thirteen times more risks of harbouring T76 resistant mutant $P$. falciparum strain compared to individuals who do not use CQ [OR $=0.08$, 95\% CI (0.05-0.12), $\mathrm{p}<0.001]$. The risk of stocking CQ in an area or using CQ and becoming infected with $P$. falciparum with T76 mutation is shown in Table 3. CQ 


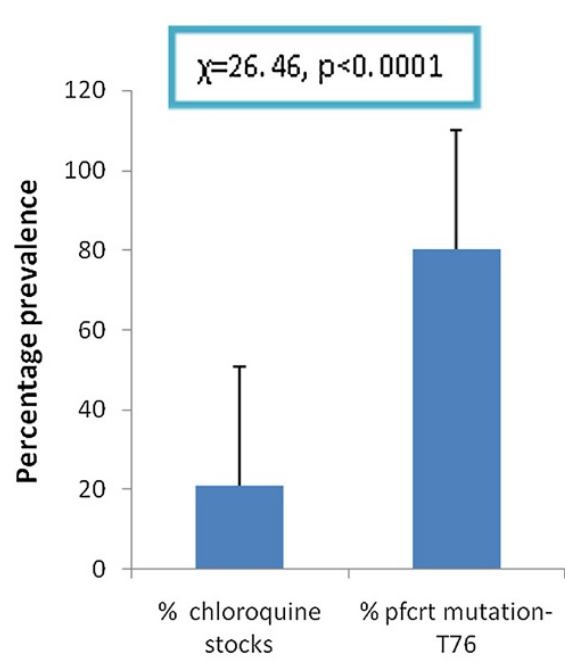

Cape Coast

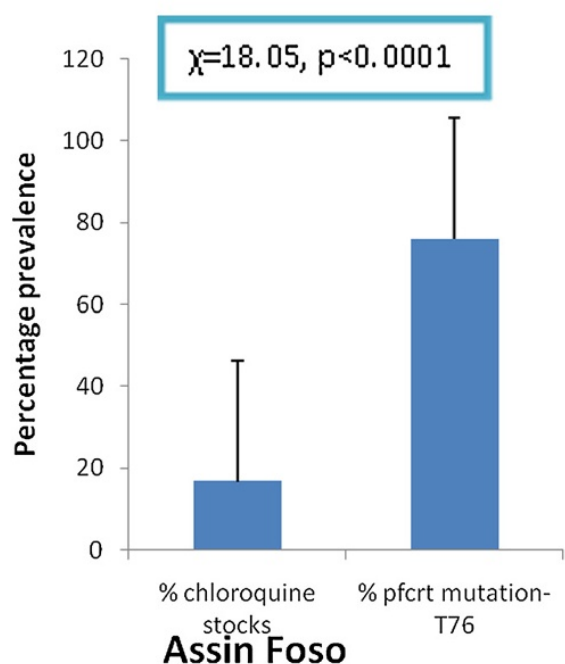

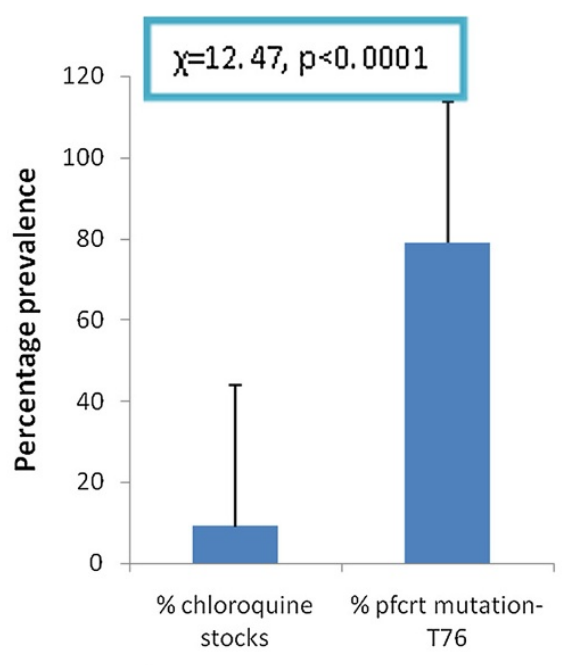

Elmina

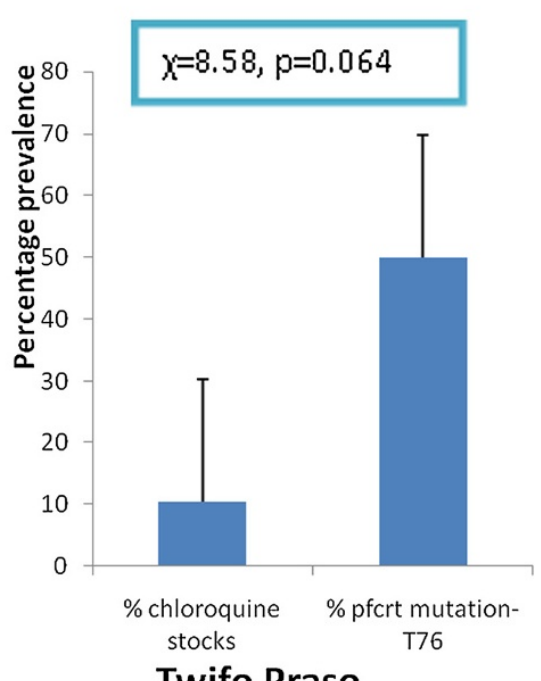

Twifo Praso

Figure 2 Association between urine chloroquine levels and prevalence of K76T of pfcrt K76T mutation in the study sites. The $\%$ urine chloroquine indicates the prevalence of chloroquine use among the study subjects.

Table 3 Association between CQ stocks and/or CQ in urine and the risk of acquiring infection with CQ resistant $P$. falciparum strains

\begin{tabular}{|c|c|c|c|c|}
\hline \multirow[t]{2}{*}{ Study sites } & \multicolumn{2}{|c|}{ CQ stocks and prevalence of T76 mutation of pfcrt } & \multicolumn{2}{|c|}{ Urine $\mathrm{CQ}$ and prevalence of T76 mutation of $\mathrm{pfcr}$} \\
\hline & RR & $95 \% \mathrm{Cl}$ & OR & $95 \% \mathrm{Cl}$ \\
\hline Cape Coast & 0.26 & $(0.11-0.63)^{\mathrm{HS}}$ & 0.07 & $(0.03-0.18)^{\mathrm{HS}}$ \\
\hline Elmina & 0.10 & $(0.02-0.66)^{\mathrm{S}}$ & 0.04 & $(0.02-0.11)^{\mathrm{HS}}$ \\
\hline Twifo Praso & 0.21 & $(0.06-0.80)^{\mathrm{S}}$ & 0.19 & $(0.09-0.39)^{\mathrm{HS}}$ \\
\hline Assin Foso & 0.22 & $(0.08-0.62)^{\mathrm{HS}}$ & 0.06 & $(0.03-0.12)^{\mathrm{HS}}$ \\
\hline
\end{tabular}

HS = highly significant $(\mathrm{p}<0.001)$.

$\mathrm{S}=$ significant $(\mathrm{p}<0.05)$.

NS $=$ not significant $(p>0.05)$ 
use was also observed to be significantly associated with T76 mutation in all the study sites (Figure 2).

\section{Discussion}

Various studies since the change in malaria treatment policy in Ghana have reported different levels in prevalence of the mutant pfcrt T76 in P. falciparum isolates collected from different parts of the country $[4,5,16]$. CQ pressure is driven by high CQ usage in an area and it is a major determinant of selection and spread of CQ resistance genes among $P$. falciparum population [17-19]. The persistent treatment of $P$. falciparum infections with CQ will subsequently encourage the selection of $C Q$ resistant strains [20-23]. The danger is that there could be subsequent selection of additional changes in genes regulating $P$. falciparum response to CQ [24-28]. Such a situation will favour cross-resistance between CQ and amodiaquine, which is co-partner of artesunate, the first ACT deployed in Ghana [28-30].

In this study, the risks of becoming infected with T76 mutant of $p f c r t$ gene of $P$. falciparum isolates was strongly associated with staying at a place where community pharmacies and chemical shops stock CQ for sale or where there is CQ usage. This observation is supported by several field studies in different geographical sites that have shown absolute specificity of pfcrt T76 molecular marker to predict CQ resistance both in vitro and in vivo [31,32]. The high prevalence of the $p f c r t$ T76 mutation recorded in this study after eight years of discontinuous usage of CQ in Ghana is an indication of circulation of CQ resistant strains. The transmission of the T76 mutant of pfcrt gene is possible in the study areas because it has been shown elsewhere that there is a high gametocyte carriage and infectivity of resistant parasites by mosquitoes than the drug sensitive types [33,34]. The detection of traces of $\mathrm{CQ}$ in the urine samples of study subjects confirms CQ usage, a factor responsible for the development of $\mathrm{CQ}$ resistance. It is, therefore, speculated that CQ usage and not AS-AQ combination usage that selects pfcrt T76 resistance. The observed high prevalence of the pfcrt T76 mutation is similar to the Uganda study where CQ was substituted with artemether-lumefantrine (AL) as the first-line anti-malarial drug $[35,36]$. After seven years of AL usage, CQ resistance was still high, ranging from 98.7 to $100 \%[35,36]$. The increase in the observed resistance in those reports was attributed to continuous use of $C Q$, the same reason adduced by this study. In support of this speculation are two separate reports that did not find any association between pfcrt T76 and sulphadoxine-pyrimethamine-amodiaquine combination in treatment failure after four years [37] as well as pfcrt T76 in vitro resistance studies after eight years of using amodiaquine combination at Pikine, Senegal [38].
It has been demonstrated in this study that the level of CQ stocking and usage is significantly associated with the prevalence of pfcrt T76 mutation within a study site. This support the argument that emergence of CQ resistance is influenced by intensity of CQ usage [39-42]. The mutations in pfcrt have been identified to confer and improve the fitness and stability of parasites containing the T76 mutation [43,44]. The detection of high prevalence of some point mutations of $p f m d r 1$ in Central region of the country (unpublished data) also augments the fitness and stability of CQ resistant $P$. falciparum strains in the study sites. The current high prevalence of $p f c r t$ threatens anti-malarial treatment policy in the country. Since mutations in $p f c r t$ have shown to confer resistance to amodiaquine which co-partners artesunate in the combination therapy as first line malaria treatment regimen in the country, it is important to constantly monitor the efficacy of all ACT regimen especially amodiaquine-based ACT for early detection of $P$. falciparum resistance $[16,26,32,45-48]$. Also the level of quinine and amodiaquine resistance [5] as well as treatment failures with artesunate + amodiaquine in the country requires constant monitoring.

The differences in the distribution of pfcrt T76 resistance gene among the four study sites were constantly related to the different pattern of CQ stocking and usage in each area. This suggests that complete withdrawal of CQ from the country could lead to re-emergences of CQ sensitive $P$. falciparum similar to the findings from other endemic countries $[35,36,49,50]$.

The reason for stocking CQ by community pharmacies and chemical shops was unknown, however CQ is cheaper and this may account for people patronizing [51,52] it after its ban. Additionally, subjects who have strong perceptions about the efficacy and efficiency of CQ for malaria treatment [51-53] still patronized it. Therefore, switching from CQ to ACTs has become very difficult for them. Other studies conducted in various parts of Ghana and other countries also indicated the continuous usage of CQ [53-55].

\section{Conclusion}

The findings gave evidence that the significant variations in pfcrt T76 of P. falciparum isolates in some parts of Ghana are highly associated with the sale and use of CQ in these communities.

\section{Competing interests}

The authors declared that there is no conflict of interest.

Authors' contributions

KKA performed the experiment experiments, interpreted the data and drafted the manuscript. KKA, JNB, NBQ, RS designed the study. JNB, NBQ supervised the entire work and revised the manuscript. KKA, RA, EOA participated in laboratory analysis, provided statistical expertise in analysing 
the data and participated in drafting the manuscript. All authors read and approved the final version of the manuscript.

\section{Acknowledgements}

This work was supported by Department of Biomedical and Forensic Sciences, University of Cape Coast. We are grateful to the laboratory and the medical staffs of St. Francis Xavier hospital, Cape Coast Metropolitant hospital, Twifo Praso district hospital and Elmina Urban Health Centre especially, Mr Mends, the district director of health services KEEA district, Dr. Annan and Dr. Oppong-Nkrumah of Twifo Praso district hospital for their support.

\section{Author details}

'Department of Biomedical and Forensic Sciences, University of Cape Coast, Cape Coast, Ghana. ${ }^{2}$ Department of Medical Parasitology, Postgraduate Institute of Medical Education and Research, Chandigarh 160012, India. ${ }^{3}$ Centre for Tropical Clinical Pharmacology and Therapeutics, University of Ghana Medical School, P O Box GP4236, Accra, Ghana.

Received: 2 February 2014 Accepted: 19 June 2014

Published: 26 June 2014

\section{References}

1. Afari EA, Akanmori BD, Nakano T, Ofori-Adjei D: Plasmodium falciparum: sensitivity to chloroquine in vivo in three ecological zones in Ghana. Trans R Soc Trop Med Hyg 1992, 86:231-232.

2. Koram KA, Abuaku B, Duah N, Quashie N: Comparative efficacy of antimalarial drugs including ACTs in the treatment of uncomplicated malaria among children under 5 years in Ghana. Acta Trop 2005, 95:194-203.

3. WHO: World Malaria Report 2008. Geneva: World Health Organization; 2008.

4. Abruquah H, Bio F, Tay S, Lawson B: Resistance-mediating polymorphisms of Plasmodium falciparum among isolates from children with severe malaria in kumasi, ghana. Ghana Med J 2010, 44:52-58.

5. Kwansa-Bentum B, Ayi I, Suzuki T, Otchere J, Kumagai T, Anyan WK, Osei JH, Ashi H, Ofori MF, Akao N, Wilson MD, Boakye DA, Ohta N: Plasmodium falciparum isolates from southern Ghana exhibit polymorphisms in the SERCA-type PfATPase6 though sensitive to artesunate in vitro. Malar J 2011, 10:187.

6. Duah NO, Matrevi SA, de Souza DK, Binnah DD, Tamakloe MM, Opoku VS, Onwona CO, Narh CA, Quashie NB, Abuaku B, Buplessis C, Kronmann KC, Koram KA: Increased pfmdr1 gene copy number and the decline in pfcrt and pfmdr1 resistance alleles in Ghanaian Plasmodium falciparum isolates after the change of anti-malarial drug treatment policy. Malar J 2013, 12:377.

7. Quashie NB, Duah NO, Abuaku B, Quaye L, Ayanful-Torgby R, Akwoviah GA, Kweku M, Johnson JD, Lucchi NW, Udhayakumar V, Duplessis C, Kronmann KC, Koran KA: A SYBR Green 1-based in vitro test of susceptibility of Ghanaian Plasmodium falciparum clinical isolates to a panel of anti-malarial drugs. Malar J 2013, 12:450.

8. Cooper RA, Hartwig CL Ferdig MT: pfcrt is more than the Plasmodium falciparum chloroquine resistance gene: a functional and evolutionary perspective. Acta Trop 2005, 94:170-180.

9. Djimde AA, Doumbo OK, Traore O, Guindo AB, Kayentao K, Diourte $Y$, Niare-Doumbo S, Coulibaly D, Kone AK, Cissoko Y, Tekete M, Fofana B, Diallo DA, Wellems TE, Kwiatkowski D, Plowe CV: Clearance of drug-resistant parasites as a model for protective immunity in Plasmodium falciparum malaria. Am J Trop Med Hyg 2003, 69:558-563.

10. Fidock DA, Nomura T, Talley AK, Cooper RA, Dzekunov SM, Ferdig MT, Ursos LM, Sidhu AB, Naude B, Deitsch KW, Su XZ, Wootton JC, Roepe JD, Wellems TE: Mutations in the $P$. falciparum digestive vacuole transmembrane protein PfCRT and evidence for their role in chloroquine resistance. Mol Cell 2000, 6:861-871.

11. Wootton JC, Feng X, Ferdig MT, Cooper RA, Mu J, Baruch DI, Magill AJ, Su X: Genetic diversity and chloroquine selective sweeps in Plasmodium falciparum. Nature 2002, 418:320-323.

12. Duah NO, Wilson MD, Ghansah A, Abuaku B, Edoh D, Quashie NB, Koram KA: Mutations in Plasmodium falciparum chloroquine resistance transporter and multidrug resistance genes, and treatment outcomes in Ghanaian children with uncomplicated malaria. J Trop Pediatr 2007, 53:27-31.
13. Bereczky S, Måtersson A, Gil PJ, Färnert A: Rapid DNA extraction from archive blood spots on filter paper for genotyping of Plasmodium falciparum. Am J Trop Med Hyg 2005, 72:249-251.

14. Djimde A, Doumbo OK, Cortese JF, Kayentao K, Doumbo S, Diourte $Y$, Coulibaly D, Dicko A, Su XZ, Nomura T, Fidock DA, Wellems TE, Plowe CV: A molecular marker for chloroquine-resistant falciparum malaria. N Engl J Med 2001, 344:257-263.

15. Steketee RW, Mount DL, Patchen LC, Williams SB, Churchill FC, Roberts JM, Kaseje DC, Branding-Bennett AD: Field application of a colorimetric method of assaying chloroquine and desethylchloroquine in urine. Bull World Health Organ 1988, 66:485-490.

16. Afoakwah R, Boampong JN, Egyir-Yawson A, Nwaefunab EK, Verner ON, Asare KK: High prevalence of PfCRT K76T mutation in Plasmodium falciparum isolates in Ghana. Acta Trop 2014, 136:32-36.

17. Abdel-Muhsin AA, Mackinnon MJ, Awadalla P, Ali E, Suleiman S, Ahmed S, Walliker D, Babiker HA: Local differentiation in Plasmodium falciparum drug resistance genes in Sudan. Parasitol 2003, 126:391-400.

18. Conway DJ: Molecular epidemiology of malaria. Clin Microbiol Rev 2007, 20:188-204.

19. Sisowath C, Petersen I, Veiga MI, Martensson A, Premji Z, Bjorkman A, Fidock DA, Gil JP: In vivo selection of Plasmodium falciparum parasites carrying the chloroquine-susceptible pfcrt K76 allele after treatment with artemether-lumefantrine in Africa. J Infect Dis 2009, 199:750-757.

20. Best Plummer W, Pinto Pereira LM, Carrington CV: Pfcrt and pfmdr1 alleles associated with chloroquine resistance in Plasmodium falciparum from Guyana, South America. Mem Inst Oswaldo Cruz 2004, 99:389-392.

21. Buckling AJ, Taylor LH, Carlton JMR, Read AF: Adaptive changes in Plasmodium falciparum transmission strategies following chloroquine chemotherapy. Proc R Soc 1997, 264:553-559.

22. Targett G, Drakeley C, Jawara M, Seidlein L, Colema R, Deen J, Pinder M, Doherty T, Sutherland C, Walraven G, Milligan P: Artesunate reduces but does not prevent post treatment transmission of Plasmodium falciparum to Anopheles gambiae. J Infect Dis 2001, 183:1254-1259.

23. White NJ, Pongtavornpinyo W: The de novo selection of drug-resistant malaria parasites. Proc Biol Sci 2003, 270:545-554.

24. Foote SJ, Kyle DE, Martin RK, Oduola AM, Forsyth K, Kemp DJ, Cowman AF: Several alleles of the multidrug-resistance gene are closely linked to chloroquine resistance in Plasmodium falciparum. Nature 1990, 345:255-258.

25. Dorsey G, Staedke S, Clark TD, Njama-Meya D, Nzarubara B, MaitekiSebuguzi C, Dokomajilar C, Kamya MR, Rosenthal PJ: Combination therapy for uncomplicated falciparum malaria in Ugandan children: a randomized trial. JAMA 2007, 297:2210-2219.

26. Reed MB, Saliba KJ, Caruana SR, Kirk K, Cowman A: Pgh1 modulates sensitivity and resistance to multiple antimalarials in Plasmodium falciparum. Nature 2000, 403:906-909.

27. Sidhu $A B$, Valderramos SG, Fidock DA: pfmdr1 mutations contribute to quinine resistance and enhance mefloquine and artemisinin sensitivity in Plasmodium falciparum. Mol Microbiol 2005, 57:913-926.

28. Dokomajilar C, Lankoade MZ, Dorsey G, Zongo I, Ouedraogo JB, Rosenthal PJ: Roles of specific Plasmodium falciparum mutations in resistance to amodiaquine and sulfadoxine-pyrimethamine in Burkina Faso. Am J Trop Med Hyg 2006, 75:162-165.

29. Ochong EO, van den Broek IVF, Keus K, Nzila A: Association between chloroquine and amodiaquine resistance and allelic variation in the Plasmodium falciparum multiple drug resistance 1 gene and the chloroquine resistance transporter gene in isolates from the upper Nile in southern Sudan. Am J Trop Med Hyg 2003, 69:184-187.

30. Holmgren G, Gil JP, Ferreira PM, Veiga MI, Obonyo CO, Bjorkman A: Amodiaquine resistant Plasmodium falciparum malaria in vivo is associated with selection of pfcrt 76T and pfmdr1 86Y. Infect Genet Evol 2006, 6:309-314.

31. Valderramos SG, Valderramos JC, Musset L, Purcell LA, Mercereau-Puijalon O, Legrand E, Fidock DA: Identification of a mutant PfCRT-mediated chloroquine tolerance phenotype in Plasmodium falciparum. PLoS Pathog 2010, 6:e1000887.

32. Woodrow CJ, Krishna S: Antimalarial drugs: recent advances in molecular determinants of resistance and their clinical significance. Cell Mol Life SCi 2006, 63:1586-1596.

33. Handunnetti SM, Gunewardena DM, Pathirana PP, Ekanayake K, Weerasinghe S, Mendis KN: Features of recrudescent chloroquine-resistant 
Plasmodium falciparum infections confer a survival advantage on parasites and have implications for disease control. Trans $R$ Soc Trop Med Hyg 1996, 90:563-567.

34. Barnes Kl, White NJ: Population biology and antimalarial resistance: The transmission of antimalarial drug resistance in Plasmodium falciparum. Acta Trop 2005, 94:230-240.

35. Kiwuwa MS, Byarugaba J, Wahlgren M, Kironde F: Detection of copy number variation and single nucleotide polymorphisms in genes involved in drug resistance and other phenotypic traits in P. falciparum clinical isolates collected from Uganda. Acta Trop 2013, 125:269-275.

36. Ucakacon PS, Achan J, Kutyabami P, Odoi AR, Kalyango NJ: Prescribing practices for malaria in a rural Ugandan hospital: evaluation of a new malaria treatment policy. Afr Health Sci 2011, 11:S53-S59.

37. Sarr O, Ahouidi AO, Ly O, Daily JP, Ndiaye D, Ndir O, Mboup S, Wirth DF: Mutations in PFCRT K76T do not correlate with sulfadoxinepyrimethamine-amodiaquine failure in Pikine, Senegal. Parasitol Res 2008, 103:765-769.

38. Ly O, Gueye PEO, Deme AB, Dieng T, Badiane AS, Ambroise D, Ahouidi AD, Diallo M, Bei AK, Wirth DF, Mboup S, Sarr O: Evolution of the pfcrt T76 and pfmdr1Y86 markers and chloroquine susceptibility 8 years after cessation of chloroquine use in Pikine, Senegal. Parasitol Res 2012, 111:1541-1546.

39. Mallick PK, Sutton PL, Singh R, Singh OP, Dash AP, Singh AK, Carlton JM, Bhasin VK: Microsatellite analysis of chloroquine resistance associated alleles and neutral loci reveal genetic structure of Indian Plasmodium falciparum. Infect Genet Evol 2013, 19:164-175.

40. Talisuna AO, Okello PE, Erhart A, Coosemans M, D'Alessandro U: Intensity of malaria transmission and the spread of Plasmodium falciparum-resistant malaria: a review of epidemiologic field evidence. Am J Trop Med Hyg 2007, 77:170-180.

41. Trassos MA, Laufer MK: Resistance to antimalarial drugs: molecular, pharmacologic, and clinical considerations. Pediatr Res 2009, 65:64-70.

42. Gbotosho GO, Happi CT, Ganiyu A, Ogundahunsi OA, Akin Sowunmi A, Oduola AM: Potential contribution of prescription practices to the emergence and spread of chloroquine resistance in south-west Nigeria: caution in the use of artemisinin combination therapy. Malar J 2009, 8:313.

43. Modrzynska KK, Creasey A, Loewe L, Cezard T, Borges ST, Martinelli A, Rodrigues L, Cravo P, Blaxter M, Carter P: Quantitative genome re-sequencing defines multiple mutations conferring chloroquine resistance in rodent malaria. BMC Genomics 2012, 13:106.

44. Anderson T, Nkhoma S, Ecker A, Fidock D: How can we identify parasite genes that underlie antimalarial drug resistance? Pharmacogenomics 2011, 12:59-85.

45. Maiga-Ascofare O, Le Bras J, Mazmouz R, Renard E, Falcao S, Broussier E, Bustos D, Randrianarivelojosia M, Omar SA, Aubouy A, Lepere JF, Jean-Francois V, Djimde AA, Clain J: Adaptive differentiation of Plasmodium falciparum populations inferred from single-nucleotide polymorphisms (SNPs) conferring drug resistance and from neutral SNPs. J Infect Dis 2010, 202:1095-1103.

46. Pickard AL, Wongsrichanalai C, Purfield A, Kamwendo D, Emery K, Zalewski C, Kalewski C, Miller RS, Meshnick SR: Resistance to antimalarials in Southeast Asia and genetic polymorphisms in pfmdr1. Antimicrob Agents Chemother 2003, 47:2418-2423.

47. Sa JM, Twu O, Hayton K, Reyes S, Fay MP, Ringwald P, Wellems TE: Geographic patterns of Plasmodium falciparum drug resistance distinguished by differential responses to amodiaquine and chloroquine. Proc Natl Acad Sci U S A 2009, 106:18883-18889.

48. Wong RP, Karunajeewa H, Mueller I, Siba P, Zimmerman PA, Davis TM: Molecular assessment of Plasmodium falciparum resistance to antimalarial drugs in Papua New Guinea using an extended ligase detection reaction fluorescent microsphere assay. Antimicrob Agents Chemother 2011, 55:798-805.

49. Laufer MK, Thesing PC, Eddington ND, Masonga R, Dzinjalamala FK, Takala SL, Taylor TE, Plowe CV: Return of chloroquine antimalarial efficacy in Malawi. N Engl J Med 2006, 355:1959-1966.

50. Nguyen MH, Davis TM, Cox-Singh J, Hewitt S, Tran QT, Tran BK, Nguyen TH, Vo NP, Doan HN, Le DC: Treatment of uncomplicated falciparum malaria in southern Vietnam: can chloroquine or sulfadoxine-pyrimethamine be reintroduced with artesunate? Clin Infect Dis 2003, 37:1461-1466.
51. Rutebemberwa E, Nsabagasani X, Pariyo G, Tomson G, Peterson S, Kallander K: Use of drugs, perceived drug efficacy and preferred providers for febrile children: implications for home management of fever. Malar J 2009, 8:131.

52. Tarimo DS, Minjas JN, Bygbjerg IC: Perception of chloroquine efficacy and alternative treatments for uncomplicated malaria in children in a holoendemic area of Tanzania: implications for the change of treatment policy. Trop Med Int Health 2001, 6:992-997.

53. Watsierah CA, Jura WG, Oyugi H, Abong'o B, Ouma C: Factors determining anti-malarial drug use in a peri-urban population from malaria holoendemic region of western Kenya. Malar J 2010, 9:295.

54. Buabeng KO, Duwiejua M, Dodoo AN, Matowe LK, Enlund H: Self-reported use of anti-malarial drugs and health facility management of malaria in Ghana. Malar J 2007, 6:85.

55. Onwujekwe O, Uzochukwu B, Dike N, Uguru N, Nwobi E, Shu E: Malaria treatment perceptions, practices and influences on provider behaviour: comparing hospitals and non-hospitals in south-east Nigeria. Malar J 2009, 8:246.

doi:10.1186/1475-2875-13-246

Cite this article as: Asare et al:: Use of proscribed chloroquine is associated with an increased risk of pfcrt T76 mutation in some parts of Ghana. Malaria Journal 2014 13:246.

\section{Submit your next manuscript to BioMed Central and take full advantage of:}

- Convenient online submission

- Thorough peer review

- No space constraints or color figure charges

- Immediate publication on acceptance

- Inclusion in PubMed, CAS, Scopus and Google Scholar

- Research which is freely available for redistribution

Submit your manuscript at www.biomedcentral.com/submit
C) Biomed Central 